\title{
WOMEN ENTREPRENEURS IN THE RURAL MARKETS: ISSUES AND CHALLENGES
}

\author{
Sharmila Deshmukh, \\ Associate Professor, \\ Department of English, \\ Aurora's Degree\& PG College, \\ Hyderabad \\ sharmiladeshmukh74@gmail.com
}

\begin{abstract}
Women play a very important and significant role in the development of not just the family but also that of Society and Nation. In the present era of Women empowerment, their roles have significantly changed keeping in tune with the changing business world. In the backdrop of globalization, Women have indeed proved their mettle in the business world. It is not just the educated class in the urban area but women in the rural areas have geared up to meet the challenges and come up with innovative techniques in the rural markets. Seen through the Kaleidoscope of rural markets in India, one can see the broken pieces of cultural , political, regional and other challenges reflecting vibrant colours of Opportunities displaying intricate designs of creating a positive impact not just on a business enterprise but that of sketching a path towards setting a platform for Global business. As such Women comprise the major work force it is necessary to work towards their growth, security, prosperity and success which would lead to the success and growth of the business enterprise. A change is the need of the hour. The paper attempts to study the role of women in the rural markets. The study would also focus on the issues and challenges of women entrepreneurs in the rural markets, and also take the lens to the limitations of study and its applicability in other cities.
\end{abstract}

Keywords: challenges, issues, prospects, rural markets, Women Entrepreneurs

1. Introduction: In the present era, it is more important that potential Human Resources are tapped, trained and retained in order to sketch a path towards setting a platform for Global Business. This is possible when there is no discrimination with respect to Gender, Caste, Religion, Region, Language etc., It is to be noted that women in the rural market are emerging as successful entrepreneurs irrespective of their educational background. They are emerging as perfect leaders managing their homes and markets. It is in the rural markets that women have been more relaxed to be in their space for work and also balance their work at homes. They may not directly participate in the business but without their participation, the existence of rural markets is negligible. As such the recognition of women in the success of rural markets is of greater importance in providing them the necessary opportunities towards better working atmosphere, educational benefits, health benefits etc., The government has taken initiative in providing assistance through the medium of DWCRA, SHGs for the economic empowerment of women in the rural areas.

1.1 Literature Review: Rural Markets have proved to be a platform for many women to prove themselves as potential entrepreneurs nurturing their abilities and capabilities in the background of issues and challenges. Equality is an important factor in strengthening the foundation of 
the rural markets and thus placing it on a global platform. The Partner and Head of KPMG, Mr. Nischal Suri, in his plenary address at an International Conference said that Equality is one of the eight maxims for managing Human Resources. As such, women must be given equal opportunities not only to prove their mettle but also strengthen the rural markets and pave way for globalized markets. Women need family support and also that of society to step in to the shoes of their male counterparts which most of them are doing, in order to support their family. Many rural areas have potential entrepreneurs struggling to make their ends meet. Their potential is not recognized and hence remain in the background of poverty, superstition, child marriages, dowry etc. The need of the hour is to recognize such talent and tap them by providing training and development programmes, educational programmes, self help groups etc., so that their abilities are nurtured and nourished for further growth and prosperity.

\subsection{Objectives}

- To have an in depth understanding of the role women in the rural markets and study the issues and challenges faced by the women in the rural areas for the marketing and selling of their products.

- To study and analyse the strengths, weakness, opportunities and the threats to women in the rural areas.

- To evaluate the facilities given to the women in the rural markets and the facilities they are in need of. To recommend a positive and effective changing role of Women in the rural markets.

2. Methodology: There are various sources for obtaining primary data i.e., Mail survey, personal interview, Case study. Field survey, panel research and observation approach etc. The study to maximum extent depends on primary data, which is collected by way of interacting with 50 women in the village of Mudmala, Mahaboobnagar district , Telangana State.Data is collected by interview or personal interaction with women working in the agricultural farms. For the purpose of study, both primary and secondary data is collected. The explorative and analytical method of data collection is adopted. The necessary data is also collected from newspapers and other published sources. The collected data is analysed and interpreted.

2.1 Data Collection: Data collection is primary and secondary data.

2.1.1 Primary data: Primary data is personally developed data and it gives latest information and offers much greater accuracy and reliability. Interaction with women working in agricultural farms of the village, Mudmala of Mahaboobnagar District, Telangana State.

\subsubsection{Secondary data: Secondary data} is the published data. It is already available for using and its saves time.Websites ,Journals, Reports, Case Study and Newspapers

2.1.3 Sampling Design: A sample design is a finite plan for obtaining a sample from a given population. Convenience sampling 


\section{ELK}

Asia Pacific Journals

is used for this study. Cluster Sampling is also used.

2.1.4 Sample Size: Number of the sampling units selected from the population is called the size of the sample. For this study, a total population of 50 respondents working in the agricultural farms are interviewed from the village of
ELK Asia Pacific Journals - Special Issue ISBN: 978-81-930411-9-2

Mudmala, Mahabubnagar District, Telangana State. The total 50 respondents are taken in to consideration.

3. Research Findings: Considerable amount of time is spent to collect the findings of the research. The findings are stated. These findings are the basis of the recommendations that are made.

\subsection{Data Interpretation}

\subsubsection{Respondents details and Commodities sold}

\begin{tabular}{|l|l|l|}
\hline Age & No. of Respondents & Percentage \\
\hline Less than 20 years & 12 & $24 \%$ \\
\hline $21-30$ & 10 & $20 \%$ \\
\hline $31-40$ & 15 & $30 \%$ \\
\hline More than 40 years & 13 & $26 \%$ \\
\hline Total= & 50 & $100 \%$ \\
\hline Source: Primary & & \\
\hline
\end{tabular}

The women belonging to the village are agricultural farmers working in the farms and then selling the grains, vegetables etc.,.same in the neighbouring markets for their livelihood. The data shows that they are women aged less than twenty and also women aged more than forty involved in the various activities, starting from agricultural activities to marketing and selling.

\subsubsection{Commodities marketed by the respondents}

\begin{tabular}{|l|l|l|}
\hline Commodities & No. of Respondents & Percentage \\
\hline Vegetables & 12 & $24 \%$ \\
\hline Dairy & 10 & $20 \%$ \\
\hline Sea food & 15 & $30 \%$ \\
\hline Grains & 13 & $26 \%$ \\
\hline Total= & 50 & $100 \%$ \\
\hline Source: Primary & & \\
\hline
\end{tabular}

Some of the women are farmers who take the vegetables to the neighbouring villages and sell there in the Haats or weekly Melas set for the purpose. Some are involved in the dairy farming and some of them in selling sea food such as fish, prawns etc.,.
Some others are involved in selling grains. The women are involved in the packing, transportation, marketing and selling of the products. 


\subsubsection{Income of the Respondents}

\begin{tabular}{|l|l|l|}
\hline Income per month & No. of Respondents & Percentage \\
\hline Less than 3000 & 8 & $16 \%$ \\
\hline $3000-5000$ & 10 & $20 \%$ \\
\hline $5000-7000$ & 17 & $34 \%$ \\
\hline More than 7000 & 15 & $30 \%$ \\
\hline Total= & 50 & $100 \%$ \\
\hline Source : primary & & \\
\hline
\end{tabular}

The income generated is dependent on the commodities sold in the market. The earnings are again invested further for the purchase of the raw materials of the commodities, farming chemicals, preserving agents etc.,. so that the rotation is in and the business cycle continues.

\subsubsection{Educational Background of the Respondents}

\begin{tabular}{|l|l|l|}
\hline Education & No. of Respondents & Percentage \\
\hline Dropouts & 24 & $48 \%$ \\
\hline $10^{\text {th }}$ class & 16 & $32 \%$ \\
\hline Intermediate & 8 & $16 \%$ \\
\hline Degree & 2 & $4 \%$ \\
\hline Total $=$ & 50 & $100 \%$ \\
\hline Source : primary & & \\
\hline
\end{tabular}

\section{Findings}

- It is found that the majority of respondents are in the age group between 20 to more than 50 years.

- The educational level of these women is low. About $48 \%$ women dropouts and hardly $4 \%$ of them are graduates.

- Due to lack of education, most of them are not aware of the government initiatives. Illiteracy is a major hurdle in the growth prospects of these women.

- Most of the women lack medical care and facilities and suffer from depression and are not aware about the legal frame work to protect themselves.

- All of them agree that they need safety, security, economic stability and congenial working conditions and lack adequate support and guidance from family and society.

\section{Recommendations}

- Women need high motivation from family and society. Hence family disputes need to be resolved through guidance and counseling.

- Appropriate working conditions and equal pay must be practiced.

- Sufficient funds need to be allocated for their services. There 
should be an improvement in the working facilities for the women.

- Loan should be provided at lower interest rates to start the business of small groups.

- Education and Training to be provided. Create awareness about their rights and the legal work frame.

- Self Employment schemes to be implemented. Provide guidance and counseling. To bring out a change internally, externally, individually and collectively.

- To create awareness about informal trading laws. Promote DWCRA groups and SHGs to encourage economic empowerment for the women.

- Generate employment and work towards safety, health and honoring dignity of the women.

\section{Limitations}

. This study was not an exception and was carried out under the following limitations:

- The study was be limited to the Mudmala Village of Mahaboobnagar District.

- Some of the respondents may be reluctant to provide the exact information. Few respondents may be reluctant while answering the questions.

- The time is also one of the hindrances in the research.

- Some important information may not be there due to confidentiality involved in it. Accuracy of the study is limited due to the possible bias of the respondents.
- Some important information may not be there due to the lack of proper educational background of the respondents.

7. Conclusion: To conclude in the words of Dipali Goenka, MD of Welspun Global Brands, 'Work empowers women. Women bring with them EQ. They bring diversity, balance and a different thought process',

The Managing Director of Jindal Saw, the wheel bound mother of two, shares that women have in them the potential equal to men but don't have that equal opportunities. It is more important to provide basic training programmes in the rural areas with the aid of technology and further encourage them to be self reliant. It is through the intervention of many private and government agencies that many benefits are provided in the form of schemes and loans to help the women gear up their economy for better living standards. The glass ceiling effect needs to be eradicated in order to set a platform offering opportunities to blossom their skills and talent in vibrant colours of success, growth, prosperity of not just a business enterprise but that of an individual, society and Nation. Women in the rural markets are indeed a rich source of entrepreneurial skills enveloped in the ignorance of illiteracy. It is high time to recognise the skills and tap that potential to strengthen the rural markets for economic stability of not just women but that of the Nation.

\section{References:}

[1] www.ruralmarketsinindia.com

[2] Human Resources Management, L.M.Prasad 


\section{ELK}

Asia Pacific Journals
ELK Asia Pacific Journals - Special Issue ISBN: 978-81-930411-9-2

[3] Human Resources Management , Pattanayak, $2^{\text {nd }}$ edition, PrenticeHall India

[4] Strategic Human Resources Management, Anuradha Sharma and Aardhana Khandekar

[5] Times of India Publications, March 4rth, The Real Women of Substance

[6] The Times of India, March $10^{\text {th }}$ 2014, article-Women in Charge

[7] The Times of India, April $7^{\text {th }} 2014$, article- Women in Charge 